Summer 2013

\title{
Expanding Constitutionalism
}

\author{
Gunther Teubner \\ Goeth-University, g.t.eubner@jur.uni-frankfurt.de
}

Anna Beckers

Maastricht University, anna.bekers@maastrichtuniversity.nl

Follow this and additional works at: https://www.repository.law.indiana.edu/ijgls

Part of the Constitutional Law Commons, and the International Law Commons

\section{Recommended Citation}

Teubner, Gunther and Beckers, Anna (2013) "Expanding Constitutionalism," Indiana Journal of Global Legal Studies: Vol. 20 : Iss. 2 , Article 2.

Available at: https://www.repository.law.indiana.edu/ijgls/vol20/iss2/2

This Symposium is brought to you for free and open access by the Law School Journals at Digital Repository @ Maurer Law. It has been accepted for inclusion in Indiana Journal of Global Legal Studies by an authorized editor of Digital Repository @ Maurer Law. For more information, please contact rvaughan@indiana.edu.

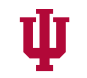

JEROME HALL LAW LIBRARY INDIANA UNIVERSITY Maurer School of Law
Bloomington 


\title{
Expanding Constitutionalism
}

\author{
GUNTHER TEUBNER* \& ANNA BECKERS ${ }^{* *}$
}

\section{NEW CONSTITUTIONAL CONFLICTS}

\begin{abstract}
Therefore pass these Sirens by, and stop your men's ears with wax that none of them may hear; but if you like you can listen yourself, for you may get the men to bind you as you stand upright on a cross-piece half way up the mast, and they must lash the rope's ends to the mast itself, that you may have the pleasure of listening. If you beg and pray the men to unloose you, then they must bind you faster. ${ }^{1}$
\end{abstract}

With these words, Homer tells us in the Odyssey that the beautiful witch-goddess Circe warned Ulysses against the Sirens. Sirens were dangerous creatures, beautiful bird-like seductresses who lured nearby sailors with their enchanting music and voices to shipwreck on the rocky coast of their island. But with cunning obedience, Ulysses followed Circe's advice. Tying his hands to the mast, he not only saved his ship from wreckage but also could listen joyfully to the sirens' singing without falling for their deadly temptation. We can not only achieve sheer survival but also higher degrees of freedom through intelligent self-restraint. Freedom through self-restraint is Ulysses' constitutional message.

Jon Elster applies Ulysses' constitutional message to the individual rational actor. He criticizes the notion of rationality using economics, a discipline concerned with maximizing the satisfaction of agents' present

* Professor of Private Law and Legal Sociology, Principal Investigator, Excellence Cluster "Normative Orders," Goethe-University Frankfurt/Main, Germany.

** Ph.D Researcher at Maastricht European Private Law Institute, Maastricht University, The Netherlands

1. HOMER, ODYSSEE bk. XII (Samuel Butler trans., 1900) (Ancient Greece n.d.), available at $\mathrm{http}: / / \mathrm{www}$. sacred-texts.com/cla/homer/ody/ody $12 . \mathrm{htm}$.

Indiana Journal of Global Legal Studies Vol. 20, Issue 2 (2013)

(c) Indiana University Maurer School of Law 
preferences. ${ }^{2}$ Individual freedom through self-restraint means avoiding "irrational" desires. ${ }^{3}$

But Ulysses' message is relevant not only for the individual. Instead, it concerns the constitution of the crew, the ship, and the collective enterprise of the Odyssey. In this collective dimension, Homer anticipates one of the strangest phenomenon which emerged in the modern nation-states' political constitutions. The deadly temptations of power cannot be overcome by external restraints; instead, power needs to restrain itself. Self-limitations of power-here lies the historical success of nation-state constitutions: checks and balances; division of powers; procedural constraints on decisions; constitutional rights; and, more recently, Ewigkeitsklausel (eternity clauses), which block the democratic majority from abolishing human rights and democracy.

However, if we look closer to the situation, we realize that there are many sirens attacking Ulysses' ship. The great error of state centrism in constitutional theory and practice is that it only addresses one temptation. Concentrating on the excesses of state power meant turning a blind eye to the manifold other sirenic temptations. Not only Thelxiepeia, but also Molpe, Aglaophonos, Peisithoe, Parthenope, Ligeia, Leucosia, Raidne, and Teles try to lure Ulysses' crew with their seductive voices. Similarly, constitutional dangers are not only created by power but also by money, knowledge, technology, and medicine.

Today, the great constitutional conflicts are not only about the state constitution but also about the many constitutions within global society. The battlefields are the global constitution of the finance economy, of science and technology, and of the new digital media. 4 Postmodern society is exposed to expansive, even totalitarian, tendencies of a variety of partial rationalities: monetarization, commodification, scientification, juridification, and medicalization. This is where Michel Foucault's "capillary power" creeps in from the different disciplines within society, not just from the old "capital power" of the state. ${ }^{5}$ It finds its constitutional reaction in Jacques Derrida's concept of the "capillary constitutions" within the many discourses in society. ${ }^{6}$

To be more concrete: during the last few years, a series of public scandals have raised the "new constitutional question." Multinational corporations have violated human rights; the World Trade

2. See generally JON ELSTER, ULYSSES AND THE SIRENS: STUDIES IN RATIONALITY AND IRRATIONALITY (1979).

3. See id.

4. For a monograph treatment, see generally GUNTHER TEUBNER, CONSTITUTIONAL FRAGMENTS: SOCIETAL CONSTITUTIONALISM AND GLOBALIZATION (2012).

5. Michel Foucault, Discipline AND PUNISH: The BIRTH OF THE PRISON 198 (1995).

6. Id.; JACQUES DERRIDA, L'AUTRE CAP [THE OTHER HEADING] 44 (1991) (Fr.). 
Organization's decisions have endangered the environment and human health in the name of global free trade; there has been doping in sport; there has been corruption in medicine and science; private intermediaries have threatened freedom of conscience on the Internet; there have been massive invasions of privacy through data collection by private organizations; and global capital markets have unleashed catastrophic risks. Each of these scandals poses questions of external regulation and the internal constitution of these social sectors.

Where exactly lies the constitutional challenge beyond the nation-state? Homer tells us the Sirens' temptation lies in what we would call collective addiction. As Walter Copland Perry observed: "Their song, though irresistibly sweet, was no less sad than sweet, and lapped both body and soul in a fatal lethargy, the forerunner of death and corruption." The sirens' irresistible temptation to perform social activities in spite of self-damaging consequences is not only individual but also predominantly social. It is the temptation of the whole crew sailing toward the riffs. Social addiction remains forever and cannot be healed, but it may be domesticated by constitutional self-restraints.

Societal constitutionalism asks for the collective redefinition of individual addiction-compulsive engagement in an activity despite lasting negative consequences-to be rethought for social systems in general and for collective actors in particular. Which "addiction mechanisms" are responsible for the fact that the autopoietic self-reproduction of several social sectors through the recursivity of system-specific operations reverts into a communicative compulsion to repetition and growth, bringing self-destructive consequences in its wake?

There is nothing necessary about the catastrophe and about Max Weber's "iron cage" of modernity. ${ }^{8}$ The occurrence of catastrophe is contingent. It depends on whether countervailing structures will emerge that prevent the positive feedback catastrophe. The "constitutional moment" is not the moment when the self-destructive dynamic makes the abstract danger of a collapse appear. Rather, it is the moment when the collapse is directly imminent. It is not yet Circe warning Ulysses, but it is the imminent arrival of the Sirens when the deadly danger of the birds strikes. This is the moment of crisis in the collective addiction: the moment where collective energies are released. It is the moment when Ulysses' cunning strategy of self-binding actually works.

7. Walter Copland Perry, The Sirens in Ancient Literature and Art, ThE NineteEnTH CENTURY, July-Dec. 1883, at 117 .

8. MAX WeBer, ECONOMY AND SociETY 1402 (Guenther Roth \& Claus Wittich eds., Ephraim Fischoff trans., Univ. Cal. Press, 4th ed. 1978) (1922). 
In the self-energizing processes of maximizing subrationalities, self-correction is only possible at the very last minute. The similarity with individual addiction therapies is obvious: Hit the bottom! It must be one minute before midnight. Only then does today's addictive society have a chance of self-correction. Only then is the understanding lucid enough, the suffering severe enough, and the will to change strong enough to allow a radical change of course.

Societal constitutionalism identifies those constitutional moments in politics. One moment was in 1945 when the United Nations Declaration of Human Rights was accepted worldwide after the atrocities of totalitarian regimes. In functional differentiation, all subsystems of society develop massive growth energies that are excessively ambiguous in their productivity and in their destructiveness. But constitutional moments also occur in many sites of global society. We have experienced constitutional moments in the global economy. Some global constitutional moments happened in 1929 and 2008 when the collapse of powerful banks triggered social movements for a worldwide financial constitution. Recently, science and technology had their constitutional moment in 2011 when the Fukushima disaster signaled the limits to nuclear industry. Even the so-called humanistic discipline of medicine experienced its moment in 1943 when Dr. Mengele performed human experiments on concentration camp inmates, including children. And we are waiting for the constitutional moment to occur in the digital world. Google and Facebook's data manipulations sound like early warnings.

Exogenous self-binding was Ulysses' constitutional strategy. Obviously this is a paradox. How did he overcome the paradox of the internal self-binding of the sovereign's will triggered from the outside? A twofold externalization shows the way out for constitutionalism. Circe's magic authority created external learning pressures for Ulysses' self-restraint, and when he delegated the bindingness of his promise to the crew, he blocked his own urges to unbind himself from his pre-commitment. 9

\section{CORPORATE CODES OF CONDUCT: AN EXAMPLE OF SOCIETAL CONSTITUTIONALISM}

Following the metaphor of Ulysses, twofold externalization combined with internal self-reflection are the fundamental prerequisites to productively transform the experience of crisis into a constitutional moment. This constitutional moment then may give rise to a stable societal constitution for the regime, network, organization, or system-

9. See HOMER, supra note 1, bk. XII. 
in the following generally social sector-at stake. To be sure, the theory of societal constitutionalism does not explicitly rely on an intrinsic, voluntary motivation of social sectors to enter into a self-limiting process. Conversely, predicting that these rules on self-limitation are developed voluntarily would imply a false idealism and would overestimate the potential of self-regulation to solve such constitutional conflicts. Although the social sector is the only competent authority to introduce self-limitations, realistically, it is often not willing to do so. ${ }^{10}$ Faced with this competence-motivation dilemma, the catastrophe is both pivotal and inevitable. The important question is then: How could the moment of catastrophe, where the self-destructive consequences of the own operations become existential, push the sector into a constitutional process? The theory of societal constitutionalism suggests that what is needed is sufficient external pressure that triggers a process of internal self-reflection, which is subsequently externally stabilized. ${ }^{11}$ Pressure, internal self-constraint, and external stabilization are thus the key components that make societal constitutions possible. ${ }^{12}$

\section{A. Pressure Against Growth Tendencies: NGOs, Consumers, Politics, and Law}

The first important condition for a constitutional moment is accordingly sufficient pressure that calls for self-limitation. Only strong external and internal pressures allow societies to overcome the competence-motivation dilemma and "force" the social sector into a self-restricting process. Such pressure may come from the outsidesocial movements, nongovernmental organizations (NGOs), media, and intellectuals-and from the inside-consumer and investor pressure in the economy, shareholder activism, or users contesting against Internet intermediaries. ${ }^{13}$ Yet, in addition, political intervention by means of regulation and legal liability may become external pressures. ${ }^{14}$

10. With respect to corporations, similar observations have been made already by Neil Gunningham \& Joseph Rees, Industry Self-Regulation: An institutional perspective, 19 LAW \& SOC'Y 363, 390 (1997) ("A useful starting point is to recognize that there is commonly a substantial gap between the self-interest of an industry or an individual enterprise, and that of the public ... Where a large gap does indeed exist, then it would be naive . . . to rely upon an individual enterprise or industry association taking steps voluntarily in the public interest").

11. For these elements as pivotal conditions for societal constitutionalism extensively, see TEUBNER, supra note 4 , at ch. IV.

12. See id.

13. Id. at 84 .

14. Id. 
Consider the codes of conduct developed by multinationals that contain explicit commitments to respect fundamental human rights, workplace standards, the rights of local communities and indigenous people, and the natural environment. The development of these codes reveals how strong pressure generated on multinational corporations with the objective of criticizing the negative effects of their worldwide operation proved to be very influential. It is also an example where the influence of different forms of pressure can be observed. The first codes of conduct-Levi Strauss in 1992 and shortly thereafter Nike-came out of the scandalization processes initiated by NGOs and transported through the media. ${ }^{15}$ Moreover, the vast majority of corporate codes of conduct dealing with labor standards were enacted at the turn of the century. ${ }^{16}$ At this time, the famous "No Logo" campaign and the Anti-Sweatshop movement were at their peak in receiving wide public attention. ${ }^{17}$

Next to external pressure by NGOs, the internal reaction on the market was important. In this regard, consumers and investors in the last decade have paid increasing attention to the social and environmental performance of corporations instead of just the price and quality of provided goods and services. ${ }^{18}$ For example, the FairTrade Labelling Organization, an umbrella NGO that certifies products that are manufactured or grown under fair labor conditions, observed roughly a triplication in sales of certified products between 1997 and

15. For the interaction of codes of conduct and civil society pressure, see generally Doreen McBarnet, Corporate Social Responsibility Beyond Law, Through Law, for Law: The New Corporate Accountability, in ThE New CoRPorate ACCOUNTABILITY: CoRPorate SocIAL RESPONSIBILITY AND THE LAW 9, 14-17 (Doreen McBarnet et al. eds., 2007). For detailed analyses with respect to different companies, see, for example, VIRGINIA Haufler, a Public Role for the Private Sector: Industry Self-Regulation in a GLOBAL ECONOMY 58-69 (2001) (apparel industry); Larry Catá Backer, Economic Globalization and the Rise of Efficient Systems of Global Private Law Making: Wal-Mart as Global Legislator, 39 CoNN. L. REv. 1739 (2007) (retail industry); Philip H. Mirvis, Transformation at Shell: Commerce and Citizenship, 105 BuS. \& SoC'Y REV. 63 (2000) (oil industry).

16. For an overview of the corporate codes development in the 1990 s, see, for example, Ans Kolk \& Rob Van Tulder, Setting new global rules? TNCs and Codes of Conduct, 14 TRANSNAT'L CORPS., no. 3, at 1, 6-7 (2005); Fabrizio Marrella, Human Rights, Arbitration, and Corporate Social Responsibility in the Law of International Trade, in ECONOMIC GLOBALISATION AND HUMAN RIGHTS 266, 294-95 (Wolfgang Benedek et. al. eds., 2007).

17. See generally NAOMI KLEIN, No LOGO: TAKING AIM AT THE BRAND BULLIES (2000) (discussing the impact of brand-name culture in the global economy and the cultural backlash that has developed in response).

18. For a monograph treatment of this changing demand structure on the market, see generally NICO STEHR, MORAL MARKETS: HOW KNOWLEDGE AND AFFLUENCE CHANGE CONSUMERS AND PRODUCTS (2008). An overview of different empirical studies on this phenomenon is provided by DAVID VOGEL, THE MARKET FOR VIRTUE 47 (2005). 
2003. ${ }^{19}$ Interestingly, such internal pressure does not only derive from consumers or private investors: in the area of public procurement, there is also evidence of how governments more frequently include social and environmental standards as a requirement in their public procurement contracts, and, in so doing, make environmental or social performance part of the contractual obligations. ${ }^{20}$

A result of this strong pressure was that corporations exposed to public criticism began to sense the negative side effects of their worldwide operation as serious risks for their reputation and as having a potential negative impact on sales. ${ }^{21}$ From their perspective, the changing expectations of customers and investors became a core reason for adapting a more responsive attitude towards respect for human rights and environmental matters. The critique on the codes as mechanisms primarily working in relation to brand-sensitive and consumer-dependent industries seems to underline this correlation rather than question it. ${ }^{22}$

Against this background, codes of conduct can in fact be understood partly as a reaction to constant pressure from NGOs and the market rather than a result of voluntary motivation. But why does societal constitutionalism understand this pressure merely as a factor for initiating a process of self-limitation instead of arguing for direct political intervention? Critics would rightly insist that past experience shows that self-limitation following societal pressure inevitably leads to new excesses and escape from effective self-limitation. In the example of

19. Fairtrade LABELling ORganizations International, ANNUAL REPORT 2003/04: SHOPPING FOR A BETTER WORLD 3, http://www.fairtrade.net/fileadmin/user_upload/content IAR_03-04_screen_final-1.pdf.

20. For the relevance of public bodies that pressure corporations into adopting social and environmental standards, see generally Christopher McCrudden, Corporate Social Responsibility and Public Procurement, in The New Corporate Accountability: CORPORATE SOCIAL RESPONSIBILITY AND THE LAW, supra note 15. For the permission of including noneconomic considerations in tender procedures pursuant to public procurement laws in general, see, for example, C-31/87, Beentjes BV v. Netherlands, 1988 E.C.R. 4635; C-255/98, Comm'n v. France, 2000 E.C.R. I-7445; C-513/99, Concordia Bus Finland, 2002 E.C.R. I-7213; C-448/01, EVN AG and Wienstrom GmbH v. Republik Österreich, 2003 E.C.R. I-14527; c.f. C-368/10 Comm'n v. Netherlands (2012) (not yet published in the official journal) (restricting public authorities from only procuring products with a specific label, in this case a label that complies with the Fair Trade Labelling Organization).

21. VOGEL, supra note 18 , at 52.

22. For this criticism, see, for example, RHYS JENKINS, UNITED NATIONS RESEARCH INST. FOR SOC. DeV., CORPorate CODES OF CONDUCT: SElf-REgulation IN A Global ECONomy 27 (2001); Doreen McBarnet \& Marina Kurkchiyan, Corporate Social Responsibility Through Contractual Control? Global Supply Chains and "Other Regulation", in THE NEW CORPORATE ACcounTabilitY: CORPORATE SOCLAL RESPONSIBILITY AND THE LAW, supra note 15 , at 59, 83-84. 
codes of conduct, this concern reveals itself in the ongoing criticism on the vague and unenforceable character of the codes: the codes are seen as an example of how corporations react to social pressure by adopting vague policy statements that only imitate regulation. ${ }^{23}$ Consequently, it is external regulation instead of internal codes of conduct that is called for.

Indeed, the claim for external regulation seems plausible, but only at first sight. Past experience has equally shown how in many cases attempts to control internal processes through external intervention failed due to the lack of knowledge and competence of external authorities. ${ }^{24}$ And regulatory initiatives were also regularly criticized because of their inherent limited reach, allowing corporations to identify potential gaps and thus circumventing regulatory intervention. If this experience is also taken into consideration, it becomes indeed difficult to fall back on the familiar concept of political-legal intervention. But how can we then still make sense of politics and law in the theory of societal constitutionalism?

Homer gives some hints on that. Although not being competent to order the sailors or being present in the situation where the deadly temptation arose, Circe-the magic authority-remained important. She advised Ulysses on how to pass by the Island of Sirens. What can be learned from this metaphor? Firstly, only those being competent and having the situational knowledge can initiate the process of self-limitation. The closure of transnational corporations is, in fact, a serious hindrance that prevents politics and law from effective intervention. ${ }^{25}$ Hence, a process of internal self-reflection may be more powerful than any external intervention because it directly reaches the core of the corporation and may there lead to long-term changes. Yet, this is not a claim for deregulation and liberalization, as

23. See, e.g., JENkINS, supra note 22; John Christopher Anderson, Respecting Human Rights: Multinational Corporations Strike Out, 2 U. PA. J. LAB. \& EMP. L. 463, 489-90 (1999); Eva Kocher, Corporate Social Responsibility: Eine gelungene Inszenierung?, 43 KRITISCHE JUSTIZ 29, 30-31 (2010). For a critique on the specific vagueness regarding the rights to collective bargaining and freedom of association in corporate codes of conduct, see Adelle Blackett, Codes of Corporate Conduct and the Labour Regulatory State in Developing Countries, in HARD CHOICES, SOFT LAW: VolunTARY STANDARDS IN GLOBAL Trade, ENVIRonment and Social Governance 121, 126-28 (John J. Kirton \& Michael J. Trebilcock eds., 2004).

24. The failure of controlling private actors by external regulation has already been observed by others. See John Braithwaite, Enforced Self-Regulation: A New Strategy for Corproate Crime Control, 80 MICH. L. REV. 1466, 1466-67 (1982); Anthony Ogus, Rethinking Self-Regulation, 15 Ox. J. LEGAL STUD. 97, 97-98 (1995); Gunningham \& Rees, supra note 10.

25. See NikLas LuHManN, ORGanisation Und EnTSCHEIdUng [ORGantzation and DECISION] 39-79 (2000) (describing organizations as operationally closed systems) (Ger.). 
institutionalized politics and law also play an indispensable role. External guidelines and regulatory intervention may generate massive pressure on the social sector.

The influence of institutionalized politics can at least be considered partly successful in reaching corporations. That codes of conduct are merely "lip-services" without binding effect might have been true for the first generation of the codes. However, the ongoing public critique on the codes forced corporations to revise and improve their codes. ${ }^{26}$ This is also the moment where politics began to play a crucial role. In order to avoid further public exposure, corporations increasingly orientated their codes on national and international standards by adhering to guidelines enacted by international political organizations such as the United Nations, the Organisation for Economic Co-operation and Development (OECD), or the International Labour Organization (ILO). In several sectors, the international standards laid down in the conventions of the ILO are quite commonly dealt with in the codes of conduct. ${ }^{27}$ In addition, corporations investing in foreign countries attempt to draft their codes with due consideration to the technical or environmental standards of their home country. The German chemical industry, for instance, imposed internal environmental standards on their subsidiaries in foreign direct investment by transforming the standards constituted in German environmental law. The higher home country standards were integrated into the production process, but they were adjusted to the technical production specifics and the legal and technical situation in the host country. ${ }^{28}$ The application of international and national regulatory standards has indeed shown how regulatory efforts

26. An instructive example of how external pressure can lead to improvements of the codes is provided by Larry Catá Backer in this volume. See generally Larry Catá Backer, Transnational Corporations' Outward Expression of Inward Self-Constitution: The Enforcement of Human Rights by Apple, Inc., 20 IND. J. GLOBAL LEGAL STUD. 805 (2013).

27. See generally Gare Smith \& Dan Feldman, World Bank Group, Apparel, Footwear and Light Manufacturing, Agribusiness, Tourism, in 1 COMPANY CODES OF CONDUCT AND INTERNATIONAL STANDARDS: AN ANALYTICAL COMPARISON (2003) (empirical studies on content of codes of conduct); see also, McBarnet \& Kurkchiyan, supra note 22, at 66 ("Though the ethical supply codes of different companies express their requirements in variety of way, their labour requirements in particular tend to echo international law and norms, effectively reproducing the fundamental principles espoused by the International Labour Organisation.") (discussing British multinationals); Louise Vytopil, Contractual Control and Labour-Related CSR Norms in the Supply Chain: Dutch Best Practices, 8 UTRECHT L. REV. 155, 166 (2012) (discussing Dutch multinationals).

28. MARTIN HERBERG, GLOBALISIERUNG UND PRIVATE SELBSTREGULIERUNG: UMWELTSCHUTZ IN MULTINATIONALEN UNTERNEHMEN [GLOBALIZATION AND PRIVATE Self-Regulation: Environmental Protection in Multinational Companies] 184-94 (2007) (Ger.). 
by national governments and international organizations may be strongly relevant for the further development of the codes.

The influence of the law should equally not be underestimated. By aiming at holding corporations liable for socially or environmentally irresponsible behavior, lawsuits against corporations have become an effective strategy to channel social pressure and initiate changes in the corporate organization. ${ }^{29}$ For a long time, the most prominent example has in this regard been the U.S. Alien Torts Claims Act (ATCA) that civil society groups used in order to haul companies before courts for violating international ius cogens norms. ${ }^{30}$ Although the success of this strategy is now significantly restricted due to the very recent Supreme Court decision in Kiobel v. Royal Dutch Petroleum, ${ }^{31}$ there are still numerous strategies that are tested by civil society groups and victims to hold corporations liable for extraterritorial violations of human rights or environmental standards. ${ }^{32}$ Foreign Direct Liability litigation can be mentioned as an important example. ${ }^{33}$ Such lawsuits against multinationals have become powerful instances in different respects.

As legal proceedings are dealt with in the media, litigation first intensifies negative publicity. Companies in the extractive industries, for instance, do only to a limited extent serve the consumer market; accordingly, one may be tempted to assume that they would be more immune against the external pressures from consumers. However, this sector turned out to be more often comparably affected by tort law claims by victims, with the result of also being subject to public exposure and their negative effects on the environment and the local communities being revealed. ${ }^{34}$ Besides negative publicity and possible

29. For the influence of the legal system on corporations, see, for example, McBarnet, supra note 15, at 38-39 ("Corporate Responsibility through law").

30. See Ronen Shamir, Between Self-Regulation and the Alien Tort Claims Act: On the Contested Concept of Corporate Social Responsibiilty, 38 L. \& SOC'Y REV. 635, 655-59 (2004) (explaining ATCA litigation and its importance for pressuring corporations into self-regulatory programs).

31. Kiobel v. Royal Dutch Petroleum 133 S.Ct. 1649 (2013). See also Balintulo v. Daimler $A G$, No. 09-2778-cv(L), 2013 WL 4437057 (2nd Cir. Aug. 21, 2013).

32. See Corporate Legal Accountability Portal, BUS. \& HUM. RTS. RES. CTR., http://www.business-humanrights.org/LegalPortal/Home (last visited May 30, 2013) (providing an overview and summaries of lawsuits against multinational corporations).

33. For an extensive analysis of this strategy, see LISBETH ENNEKING, ForEIGN DIRECT LIABILITY AND BEYOND. EXPLORING THE ROLE OF TORT LAW IN PROMOTING INTERNATIONAL CORPORATE SOCLAL RESPONSIBILITY AND ACCOUNTABILITY (2012).

34. See Jonathan Drimmer, Human Rights and the Extractive Industries: Litigation and Compliance Trends, 3 J. WorLD ENERGY L. \& BUS. 121, 123-31 (2010) ("While more than two dozen companies have been targeted in these human rights actions . . no sector has been more targeted by human rights lawsuits in US courts than the extractive industry.") (discussing ATCA litigation against the extractive industries). 
reputation damages, legal proceedings against corporations contain high financial risks for companies as the high settlement payments in previous cases show. ${ }^{35}$ Yet, the effect of lawsuits against multinationals can certainly not be limited to reputational and financial risks. Human rights litigation against corporations is a pivotal means to concretize and channel social expectations and force corporations to investigate whether their existing self-limitative measures are in fact sufficient. In the words of an observer:

Human Rights have been on the CSR agenda for some time, and it has become routine practice for multinationals to sign up to voluntary human rights commitments such as the UN's Global Compact, and to include respect for human rights in their own codes of conduct. But the use of ATCA by NGOs has made it clear to multinationals that commitment without compliance is not enough. ${ }^{36}$

These examples show that the use of codes of conduct as potentially self-limitative rules did not evolve solely as a matter of corporate self-regulation. In fact, the pressure by civil society, the market, political guidance, and the legal system were pivotal to give rise to the codes. Societal constitutional processes are accordingly only successful if they are initiated by a sufficiently large degree of pressure stemming from civil society, media, politics, and the law.

\section{B. Internal Self-Reflection: Codes of Conduct as Part of Corporate Constitutionalism}

Yet, as has been mentioned above, societal constitutionalism still requires the social sector to build up internal workable self-limitations. Reflection can certainly be stimulated from the outside, but can never be replaced by it. This is because the instances putting pressure on companies lack the exact knowledge about workable and effective self-limiting measures. Transforming external pressure into internal self-reflection, rather, requires a new form of sensitivity of the social sector in which the pressures trigger a "cognitive learning" process. ${ }^{37}$

35. See id. at 130-31 (discussing the financial outcome of ATCA litigation in the extractive industry).

36. McBarnet, supra note 15 , at 39.

37. TEUBNER, supra note 4 , at 94-95. 
While human rights, workplace standards, and environmental protection were initiated due to constant external and internal pressure, the exact functioning of the codes, however, had to take place internally. The corporation is the only institution capable of regulating its own organizational structures and processes, the operation abroad, and the relations with contractual partners. The content of the codes and the institutions monitoring performance have to match the specifics of each of the affected sectors. Companies in industries that operate with a huge network of suppliers, such as garment or electronics, are particularly vulnerable to the violations of labor standards at their suppliers' factories, as the discussions on Nike or more recently Apple show. The extractive industries are particularly confronted with specific aspects of technical safety and the risk of environmental pollution that affect the rights of local communities. Bhopal, or, more recently, BP in the Gulf of Mexico gained notoriety as catastrophes where the relevance of these issues became apparent. ${ }^{38}$ It is therefore no coincidence that codes of conduct evolved in labor-intensive industries as supplier codes of conduct with a strong emphasis on workplace standards and labor rights, while the codes in extractive industries developed as corporate policy statements and internal safety guidelines with a focus on environmental pollution, technical safety, and local community impact. ${ }^{39}$

Yet, the knowledge required is not sector specific. To provide an example, Martin Herberg conducted an empirical study on the environmental programs of large corporations in the chemical industry and great differences in the individual companies' steering mechanisms,

38. Such differences between sectors as to their human rights impacts have also been emphasized by JOHN RUGGIE, JUST BUsIness: MULTINATIONAL CoRPorations AND HUMAN RIGHTS 22-26 (2013) ("Not surprisingly, the footwear and apparel industry tends to have a greater impact on workers than on communities, while the extractive industry has a large impact on communities as well").

39. See generally Dirk Holtbrügge \& Nicola Berg, Menschenrechte und Verhaltenskodizes in multinationalen Unternehmen [Human Rights and Codes of Conduct in Multinational Companies], in MENSCHEN- UND BÜRGERRECHTE: IDEENGESCHICHTE UND INTERNATIONALE BEZIEHUNGEN [HUMAN AND CIVIL RIGHTS: HISTORY OF IDEAS AND INTERNATIONAL RELATIONS] 81 (Petra Bendel \& Thomas Fischer eds., 2004) (Ger.). For the focus of labor-intensive industries such as apparel, footwear, sportswear, or agribusiness on labor rights, see Kolk \& Van Tulder, supra note 16, at 7. For the significantly lower standards regarding labor issues in the oil and gas sector and the specific focus of their codes on health and safety standards and environmental management systems, see Gare Smith \& Dan Feldman, World Bank Group, Oil and Gas, Mining, in 2 CoMPANy Codes of CONDUCT AND INTERNATIONAL STANDARDS: AN ANALYTICAL COMPARISON 5-21 (2004) ("Unlike the footwear and apparel or agribusiness industry sectors profiled in Part I, there is not the same degree of conformity among extractive companies in prohibiting the use of forced labor or child labor"). 
the way environmental objectives in foreign direct investment are realized, and the way environmental objectives are monitored. His analysis reveals that external recommendations, such as the International Organization for Standardization (ISO) environmental management systems, were revised and made more concrete, rather than strictly implemented, in order to fit in the specific organizational structure of each individual corporation as well as the legal and cultural situation in the host country. ${ }^{40}$

By the same token, supplier codes of conduct have to be adjusted to the particular legal, economic, and cultural situation of the country in which suppliers operate. A common problem is the right to collective bargaining, which is prohibited in some countries, such as China ${ }^{41}$ If local law proscribes worker councils or trade unions, corporations would have to find other mechanisms to give effect to such rights without violating their own standards or violating national law. ${ }^{42}$ In addition to local specifics, the functioning of the codes depends to a high degree on the particular relation of the corporation with its supplier. As empirical studies on working conditions at supplier factories observe, a code of conduct as such cannot abolish unacceptable working conditions. The codes lead to significant improvements of workplace standards only if they are implemented into the core business operation, adjusted to the specific situation of the supplier, supervised by the corporate center, and based on a collaborative relationship with the supplier. ${ }^{43}$

Hence, the knowledge of how to implement effective self-limitative rules lies hidden in the corporation itself. Societal pressure is then relevant for activating this knowledge. Subsequent internal self-reflection may become an effective internal limitation resulting in higher responsiveness to its social, human, and ecological environment.

40. HERBERG, supra note 28, at 127-33.

41. Li-Wen Lin, Corporate Social Accountability Standards in the Global Supply Chain: Resistance, Reconsideration and Resolution in China, 15 CARDOzO J. INT'L \& COMP. L. 321, 336-37 (2007).

42. See McBarnet \& Kurkchiyan, supra note 22, at 71 (identifying different strategies by corporations) ("In such cases, interviewees [corporate managers, the authors] reported, suppliers are still encouraged by the purchasing company to initiate some kind of workers' representative body that can operate with the consent of the management and consult with it about the running of the business ... An alternative, or supplementary strategy . . . is for companies to tackle this issue through political rather than contractual influence, working at the macro rather than the micro level, by engaging in a lobbying campaign through the Ethical Trade Organisation to change local law.").

43. See, e.g., Stephen Frenkel \& Duncan Scott, Compliance, Collaboration, and Codes of Labor Practice: The Adidas Connection, 45 CAL. MGMT. REv. 29, 43-44 (2002) (discussing the implementation of a labor code at Adidas corporation); Richard M. Locke et al., Does Monitoring Improve Labor Standards? Lessons from Nike, 35-39 (Mass. Inst. Tech. Sloan Sch. Mgmt., Working Paper No. 4612-06, 2006). 
Societal constitutionalism, however, remains realistic in that respect; not every process of self-reflection results in effective self-limitation. The large number of multinational corporations that have either vague codes of conduct ${ }^{44}$ or no code at all ${ }^{45}$ provide evidence for this.

And since there is no external knowledge on how these self-limitations will look for each of the social sectors at stake, there is only the possibility of experimenting with this peculiar relation between external pressure and internal self-reflection. Political-legal regulation and societal pressure are indeed unavoidable, but this pressure does not guarantee a transformation into the desired constitutional process. There is no alternative except to experiment with social pressure and with the possibilities of self-limitation.

\section{Candidates for External Stabilization: Multi-Stakeholder Initiatives and National Courts}

However, even a successful self-limitation alone is not sufficient. It must be externally stabilized. The paradox of exogenous self-binding - the will to be bound against one's will--has to be met. In other words: How can self-limitation be upheld even when the experience of danger fades and temptation becomes overwhelming? Ulysses met this paradox by ordering his sailors' to disobey his will and leave him tied to the mast regardless of how much he would beg for release.

In relation to societal constitutionalism, it is-as a third claim-argued that self-limitation must be backed up by external constraints. ${ }^{46}$ Experience with political constitutions shows how the paradox of self-binding has been externalized to the law. The nation-state constitution is not solely an instance of self-limitation of the political system, but also connected to the self-reflexive process of the law: 47 '“Constitution' can be reduced neither to a legal phenomenon

44. See, e.g., Vytopil, supra note 27, at 165-66 (conducting an empirical study on the content of codes of conduct in the sixteen largest Dutch corporations where almost thirty percent of the codes were classified as "weak," meaning codes containing vague phrasing, no reference to any external standards, no monitoring mechanisms, and no signature of the supplier).

45. McBarnet \& Kurkchiyan, supra note 22, at 83.

46. TEUBNER, supra note 4 , at 102-10.

47. See generally Niklas Luhmann, Verfassung als evolutionäre Errungenschaft [Constitution as Evolutionary Achievement], 9 RECHTSHISTORISCHES J. [JOURNAL FOR HISTORY OF LAW] 176 (1990) (describing the constitution as a structural coupling between politics and law) (Ger.). 
nor to a social phenomenon. It is always a double phenomenon, a linking of two actual processes." 48

Translated into the concrete example discussed here, the code of conduct, in order to become a societal constitution, does then not only have to serve as the organizing principle of the corporation, but it also needs to be connected to and stabilized by a legal process. A stable societal constitution would, for instance, be possible within the corporate organization when two processes-an organizational and a legal process-are combined in the codes. ${ }^{49}$ Following this understanding, the code of conduct then represents the top-level commitment, which determines the corporate organization, including strategic and financial decisions, on the one hand and the process of internal legal control on the other hand. The codes then "link fundamental principles of the organization with secondary legal rules."50

This, however, requires that the corporation's internal legal process enjoys a high degree of autonomy from other organizational processes within the corporate organization. In this regard, it is worth considering potential alternatives where codes of conduct might serve as linkages between the internal corporate organization and the law. Two tendencies in the development of codes of conduct might in this regard become crucial for the external stabilization.

First, corporations increasingly pursue the strategy of cooperating with external initiatives that certify code-compliance, the Fair Labor Association (FLA) or the Forest Stewardship (FSC) Council, among others. Second, codes of conduct become increasingly relevant in national law where codes of conduct are taken into account to reach a legal decision.

Concerning the first aspect, corporate codes of conduct interact with external civil society institutions. This makes multi-stakeholder initiatives therefore promising candidates to serve as external institutions constraining the internal use of the corporate codes of conduct. A striking example is FLA, the multi-stakeholder initiative. This multi-stakeholder initiative requires all participating companies to reconcile the companies' internal code of conduct with the standards of the FLA. In addition, companies are required to implement an internal system of monitoring code compliance. ${ }^{51}$ The FLA monitors the content of the internal code and the functioning of the internal monitoring

48. TEUBNER, supra note 4 , at 106.

49. Gunther Teubner, Self-Constitutionalizing TNCs? On the Linkage of "Private" and "Public" Corporate Codes of Conduct, 18 IND. J. GLOBAL LEGAL STUD. 617, 624-25 (2011).

50. Id, at 625 .

51. FAIR LABOR Assoc., FLA ChaRTER pt. IX, at 12-13 (July 30, 2013), http://www. fairlabor.org/sites/default/files/fla_charter_7-30-13.pdf. 
system on a continuous basis. Accordingly, the participating companies remain autonomous in implementing the required standards and setting up a workable system of code compliance. At the same time, they are constrained in deviating from the FLA code if they do not want to risk losing membership. Moreover, the independent monitoring conducted by FLA staff and the external assessment of the companies' internal management systems highly restrict corporations in deciding about whether or not to comply with the code. As Larry Catá Backer puts it in this volume with regard to the FLA: "Effectively, accredited companies can outsource enforcement while retaining a substantial stake in the development of both the standards to be applied and the monitoring systems applied." Thus, in the interaction between external multi-stakeholder programs and internal corporate codes, the certification process of the multi-stakeholder initiatives connects the internal self-limitative social process with a separate legal process. ${ }^{52}$

Secondly, it is also the system of national law that still plays an important role in externalizing and stabilizing the self-limitation. When corporations publish their codes in their annual reports, the codes become subject to disclosure law. The inclusion of codes of conduct into supplier agreements makes them relevant for the field of contract law. In all these fields, codes of conduct represent a connection between the internal self-limitation and the external regulation by national law. The law creates a binding effect, which resists temporary urges of the corporation to give in to the temptation and weaken, abandon, or simply ignore the code.

This relation between codes of conduct and national law has so far been most prominently debated in the field of unfair commercial practices law. In this area, a tendency can be observed how codes of conduct are interpreted as self-limitative commitments that give rise to legal liability if a company does not comply. ${ }^{53} \mathrm{~A}$ result of this tendency is that the code represents not only the top-level commitment of the corporate organization, but also the relevant legal basis to which the law connects. The example most commonly mentioned in this context is Kasky v. Nike Inc. ${ }^{54}$ In this case, the California Supreme Court held that Nike could in principal be held liable under the California Unfair

52. For the legal dimension in the multi-stakeholder certification process, see generally Jaye Ellis, Constitutionalization of Nongovernmental Certification Programs, 20 IND. J. Global LEGal STUD. 1035 (2013); Poul F. Kjaer, Transnational Normative Orders: The Constitutionalism of Intra- and Trans-Normative Law, 20 IND. J. GLOBAL LEGAL STUD. 777 (2013).

53. For the importance of unfair commercial practices law with respect to the code development see, for example, MICHAEL KERR, RICHARD JANDA, ChIP PITTS, CORPORATE SOCLAL RESPONSIBILITY. A LEGAL ANALYSIS 476-79 (2009).

54. Kasky v. Nike, Inc., 45 P.3d 243 (Cal. 2002), cert. denied, 539 U.S. 654 (2003). 
Competition and False Advertisement Act for not complying with its own code of conduct. ${ }^{55}$ The case highlights the connection between codes of conduct as internal self-limitative rules and court decisions as a potential external stabilizing instance. It is not the violation of international workplace standards that is per se a violation of unfair commercial practices law; rather, unfair commercial practices law connects to noncompliance with the internally adapted and published code of conduct and interprets this as a breach of the law. ${ }^{56}$ Hence, the code of conduct can serve as the basis for the decision about whether the corporation in fact acted legally or illegally. This illustrates how court decisions foster the role of codes as "a normative basis if multinational enterprises act improperly." 57 It may lead to a situation where national law respects the internally developed code of conduct as the applicable self-limitation but takes it as part of the duties of private actors under national law. This example indeed shows how a firm relation between codes of conduct and national law can be established. However, due to lack of case law on this issue in other areas, the success of national law in serving as a external stabilizing instance is so far still uncertain.

55. Id.; see also Michelle Sutton, Between a Rock and a Judicial Hard Place: Corporate Social Responsibility Reporting and Potential Legal Liability Under Kasky v. Nike, 72 U. MO. KAN. CITY SCH. L. REV. 1159, 1169.75 (2004) (outlining the preceding decisions by the California Superior Court, the California Court of Appeals, and the U.S. Supreme Court).

56. A similar interaction exists in the context of European Fair Trading Law. Pursuant to Art. 6 (2) of the Directive 2005/29/EC concerning unfair business-to-consumer commercial practices, a breach of unfair commercial practices law is present in the case of "noncompliance with commitments contained in codes of conduct by which the trader has undertaken to be bound." The effectiveness of this provision in serving as a stabilizing instance depends, however, largely upon whether the notion "code of conduct" will be given a broad interpretation and will also cover the codes of conduct that are discussed here. The European Commission seems to be in favor of such a broad interpretation. See GUIDANCE ON THE IMPLEMENTATION/APPLICATION OF THE DIRECTIVE 2005/29/EC ON UNFAIR COMMERCIAL PRACTICES, at 44-45, SEC (2009) 1666, (Dec. 3, 2009), available at http://ec.europa.eu/justice/ consumer-marketing/files/ucp_guidance_en.pdf. But for a critical position on this broad interpretation, see, for example, Axel Birk, Corporate Responsibility, unternehmerische Selbstverpflichtungen und unlauterer Wettbewerb [Corporate Responsibility, Company Self-Commitments and Unfair Competition], GEWERBLICHER RECHTSSCHUTZ UND URHEBERREChT (GRUR) [PROTECTION OF INTELLECTUAL PROPERTY RIGHTS] 196, 198-201 (2011).

57. Willem van Genugten \& Sophie van Bijsterveld, Codes of Conduct for Multinational Enterprises: Useful Instruments or a Shield Against Binding Liability, 7 TILBURG FOREIGN L. REV. 161, 177 (1998) (emphasis added). 


\section{TRANSNATIONAL SOCIETAL CONSTITUTIONALISM—THEORY AND PRACTICE}

Corporate codes of conduct are just one example of societal constitutions. The goal of this special issue is to discuss various aspects of transnational societal constitutionalism-its theory and practice in other potential fields of application. This idea brought together legal, political, and social science scholars to a conference in Turin in May 2012. The conference was hosted by the International University College of Turin, the Collegio Carlo Alberto, Moncalieri, Turin, The Hague Institute for the Internationalisation of Law, and Maastricht University.

After an introductory section defining the agenda, the second section scrutinizes the recent move of constitutionalism beyond the nation-state. The move toward a new constitutional pluralism goes into two different directions-the "transnational" and the "societal." The third section deals with the spatial and temporal dimensions of the new constitutional phenomena. In the fourth section, "constitutional subjects," the contributions search for societal equivalents to the political idea of "We the People," and identify transnational normative orders, multinational corporations, and global social movements as potential candidates. Finally, the fifth section, "constitutional arenas," focuses on the constitutional processes and the specific characteristics of constitutional norms in various social fields.

\section{A. Beyond Nation-State Constitutions: The Move to the "Transnational" and the "Societal"}

Certainly, transnational societal constitutionalism is a double provocation for traditional constitutional theory. Identifying constitutional phenomena on a transnational level contests the monopoly of the nation-state constitution. Moreover, assigning to various social sectors the capacity of generating autonomous constitutional norms fosters a new understanding of constitutions as a product of civil society and not solely as a matter of institutionalized politics.

From the perspective of sociological constitutional theory, Christopher Thornhill analyzes whether and how constitutional processes take place on the transnational level. ${ }^{58}$ For him, the crucial mechanism of constitution making is the formation of rights. In contrast

58. See generally Christopher Thornhill, A Sociology of Constituent Power: The Political Code of Transnational Societal Constitutions, 20 IND. J. GLOBAL LEGAL STUD. 551 (2013). 
to traditional constitutional theory that declares constituent power to be the ultimate point of regress, he argues for a reverse perspective and regards constituent power as being generated by constituted power. He analyses decisions by the European Court of Justice (ECJ), the European Court of Human Rights (ECtHR), and national constitutional courts and shows how these courts, which are rightly seen as instances of constituted power, create new power and thus become genuine instances of constituent power by referring to legal rights. For Thornhill, rights reference is accordingly the pivotal factor through which power is generated. Comparing national and transnational constitution-making, he identifies this mechanism of rights reference on both levels.

Yet there are also specific differences. On a transnational level, rights reference is not only limited to the political and legal system, but also and more frequently employed by nonpolitical and nonlegal actors. The result is that constitution-making happens in social sectors other than politics and law in a functional, "nationally cross-cutting fashion." Thornhill, however, concludes that in order for these transnational societal powers to become constituted, they need to be related to the normative apparatus of judicial control and a political regulatory framework.

Mattias Kumm focuses on the transnational dimension of constitutional pluralism. Although traditional constitutional scholarship has indeed provided rich normative ideas on the concept of legitimate authority on the level of the nation-state, the idea of constitutionalism still needs to be further scrutinized in light of the transnational embedding of nation-state constitutions. This embedding results in situations where national constitutional practice affects outsiders. Kumm defines them as "justice-sensitive externalities." A constitutional duty must be established for states to take into consideration these transnational externalities of domestic constitutional practice. Yet, these externalities need not only to be reflected in form of duties of states. More fundamentally, the existence of these externalities also questions the very idea of "We the People" as the fundament of constitutional legitimacy. In Kumm's own words: "A constitution established by 'We the People' can only claim legitimate authority over a domain in which there are no justice-sensitive externalities." 59

There are, however, motivational and epistemic obstacles that may prevent an appropriate consideration of justice-sensitive externalities. States may refuse to pay attention to them and instead focus purely on

59. See generally Mattias Kumm, The Cosmopolitan Turn in Constitutionalism: An Integrated Conception of Public Law, 20 IND. J. GLOBAL LEGAL STUD. 605 (2013). 
domestic impacts of their policies. Moreover, there is no universal global consensus on how justice may be achieved in light of these externalities. In order to overcome these obstacles, the potentially biased externalities perspective of national constitutional law has to be complemented by constitutional rules of international law that states are obliged to respect, develop, and support. It is only this constitutional system of international law that may address justice issues related to externalities and define the domain over which states can exercise legitimate authority. Hence, transnational constitutional thinking needs to focus on the interdependence of national and transnational constitutions. The externalities need to be dealt with on a transnational level, but they also need to be supported by an appropriate constitutional structure on the national level.

Emilios Christodoulidis focuses on the "societal" side of transnational constitutionalism. He critically assesses the capacity of the economy to self constitute in the shadow of institutionalized politics and its potential for an internal politicization. He argues that an internal politicization of social sectors resulting from external social pressures remains difficult to realize. Against the background of an asymmetry between social rationalities on a transnational level with the economic system becoming so powerful and overwhelming, political elements in society seem to be endangered by "market capture." This is why Christodoulidis remains sceptical about upholding the idea of mutual systemic irritation and, as a result, also the possibility of an autonomous politicization within economy. By describing economic self-limitation as a functional equivalent of politics, the political element, he submits, is in fact aligned to the functional imperative of economic rationality. If there is a democratic element in corporate codes of conduct, it is exploited by the corporate logic. Ethical consumerism remains to a large extent influenced by the logic of price.

Instead, he argues for a genuinely political element generating societal constitutions that realizes democracy and equality and works as a normative category rather than as a functional equivalent. In other words, the political has to be upheld against the rules of the market as nonnegotiable. The achievements of national political economy, such as trade unions, have to be protected against the rules of European market integration as "an injunction against the submission of the dignity of labour to the economic reasoning of comparative advantage."60

In the third contribution, Paul Schiff Berman focuses on the consequences of a multitude of societal constitutions and offers a

60. See generally Emilios Christodoulidis, On the Politics of Societal Constitutionalism, 20 IND. J. GLOBAL LEGAL STUD. 629 (2013). 
concept about how to deal with constitutional plurality. ${ }^{61}$ Assuming that a plurality of political and societal orders exists on a global level, he argues that this pluralism should neither be unified nor eliminated. Instead, constitutional diversity in transnational society is desirable, which according to him requires developing specific mechanisms, institutions, and principles. In particular, he suggests implementing choice of law mechanisms that allow for deliberation and dialogue with other societal constitutions. On the basis of several examples, Berman illustrates where such mechanisms already work in practice. For instance, they exist in the margin of appreciation doctrine of the European Court of Human Rights or the composition of juries in international courts with members of different communities.

\section{B. Spatial and Temporal Dimensions of Societal Constitutionalism}

If transnational societal constitutionalism questions the territorial state order as the only institution capable of enacting constitutions, it also deviates from the common understanding of the territorial and temporal stability of constitutions. Accordingly, the dimensions of constitutional space and time need to be further scrutinized.

Genuine transnational societal constitutions can arguably be understood as an attempt to detach the constitution from territory. Yet, this implies that societal constitutions will develop a more indirect connection to territories and, even more far reaching, a rather complex spatial dimension. In spite of societal constitutions transcending the territorial boundaries of the nation-state, the contributions seek to make sense of the dimensions of territory and space in a novel way.

Moreover, societal constitutionalism understands constitutions as dynamically evolving from social spheres with a high degree of flexibility and fluidity. Taking this into consideration, societal constitutionalism also challenges the idea of constitutions as an instance providing a high degree of stability over time and questions how societal constitutionalism changes the temporal understanding in constitutional theory.

Hans Lindahl emphasizes inclusion, exclusion, and the importance of boundaries for the theory of societal constitutionalism. $62 \mathrm{He}$ scrutinizes the way in which societal constitutions establish boundaries, spatial boundaries in particular. The capability of nonstate social

61. See generally Paul Schiff Berman, Jurisgenerative Constitutionalism: Procedural Prnciples for Managing Global Legal Pluralism, 20 IND. J. Global LeGal STUD. 665 (2013).

62. See generally Hans Lindahl, We and Cyberlaw: The Spatial Unity of Constitutional Orders, 20 IND. J. GLOBAL LEGAL STUD. 697 (2013). 
sectors to create autonomous orders arguably requires the existence of boundaries, which distinguish a "we" and "the other." These boundaries are established by a jointly acting collective with a shared normative theme. The theme determines the personal, spatial, temporal, and material boundaries of the order. Focusing on the "Declaration of the Independence of Cyberlaw," Lindahl illustrates how even the world-encompassing cyberlaw establishes spatial boundaries. Although cyberlaw has commonly been assumed to have no spatial dimension because it addresses everyone everywhere at every time, he argues how spatial boundaries become visible when focusing on those excluded from this global distribution of space.

On a more concrete level, Lindahl shows how an Islamic Somali man's attack on a cartoonist's Muhammed cartoons was more than a terrorist attack that took place in the territory and the legal order of the state of Denmark. It can also be interpreted as an attack by someone situated in an order that is spatially excluded from the Internet. In fact, the Declaration establishes spatial boundaries by excluding any religious order that contests having pictures of the prophet shown anywhere. Cyberlaw accordingly represents a genuine spatially-localizable constitutional order.

Riccardo Prandini deals with the temporal dimension of societal constitutionalism. ${ }^{63}$ Societal constitutions are increasingly described as dynamic and temporal constructs that seem to be overburdened with dealing with present social complexity. Moreover, these present constitutional structures have neither a profound grounding in the past nor a stable connection to the future. This is a problematic development because binding time has always been the central function of law and constitutions. Law must connect the past with the present to stabilize social expectations and to make future legal-illegal behavior predictable for social actors. Constitutions represent stable relations between politics and law and establish time-enduring corridors for mutual irritation between the political and the legal system. This, as a result, allows the law to fulfill its societal function and rely on the constitution as a highly stable input from politics.

With this analytical focus on time, Prandini identifies a core difference between state constitutions and societal constitutions. Societal constitutions are characterized by a high degree of future-orientation and a simultaneous marginalization of the past. By allowing a variety of public and private actors to contribute to the constitutionalism project, societal constitutions get institutionalized

63. See generally Riccardo Prandini, The Future of Societal Constitutionalism in the Age of Acceleration, 20 IND. J. GLOBAL LEGAL STUD. 731 (2013). 
faster. In addition, societal constitutions' strong focus on court decisions as constitutional centers allows them to anticipate future social consensus more rapidly than parliamentary organization. Finally, the increasing importance of scandalization indicates how alleged human rights violations are rendered immediately "illegal" without reverting to past human rights jurisdiction. Together, these characteristics show how present day societal constitutions have increasingly strengthened a temporal connection between present and future with a high degree of future-orientation rather than a connection between past and present that determined the future.

\section{New Constitutional Subjects: Transnational Normative Orders, Multinational Corporations, and Global Social Movements}

In the previous contributions, the authors underlined that societal constitutionalism includes nonstate actors. Yet, it remains to be discussed which social configurations-systems, regimes, networks, assemblages, or organizations - are capable of becoming constitutional subjects. The contributions in this section identify various candidates and suggest broadening the state-centered perspective of constitutional theory.

Poul Kjaer identifies both nation-states and transnational private orders as normative orders that are equally important for the emergence of societal constitutions. ${ }^{64}$ As a noteworthy restriction, Kjaer only acknowledges the internal formal organization of these normative orders. In order for formal organizations to develop constitutional structures, he argues that an internal organizational process within a social sector has to be connected to a set of hierarchically ordered norms and a political infrastructure. In this regard, the necessary relation to the political can be established either by a connection to national and international political institutions or by a connection to internal political structures. Subsequently, the formal organization has to delineate its own constitutional subject by mirroring its external social environment.

The classic example is the delineation of society within the state as the constitutional subject "the people" or "the nation." Analyzing the FairTrade Labelling Organization (FLO) as a constitutional subject, Kjaer illustrates this approach by interpreting the institutionalized parliamentary-like procedure adopting and revising the FLO Charter as an internal politicized organizational structure. A connection to a legal process takes place as FLO is connected to the separately incorporated

64. See generally Kjaer, supra note 52. 
entity FLO-CERT, which monitors compliance and sanctions noncompliance with the FLO Charter. The development of a genuine constitutional subject takes place when external stakeholders-producers, traders, and independent experts-become mirrored in the internal organizational structures through representatives.

Identifying multinational corporations as constitutional subjects, Larry Catá Backer broadens this perspective. ${ }^{65} \mathrm{He}$ defines them as constitutional subjects in conjunction with their fractured, fluid, permeable, and polycentric environment. He analyses how Apple Inc. introduced self-limitative structures in order to monitor social and environmental standards in its supply-chain. Autonomous self-limiting structures of corporations, he argues, can only be understood if one takes into account the dynamic social environment of their governance unit. Corporate constitutions can be defined as "stable constitutions in dynamic oscillation."66 Hence, corporations are dependent on constant, but also constantly changing, external input from various sources ranging from international politics and institutionalized multi-stakeholder initiatives to spontaneous protests and boycotts. The Apple example shows how the company's internal constitution, particularly its corporate social responsibility policy and its supplier code of conduct, developed alongside the ongoing claims for transparency raised by NGOs and consumers, and later on in collaboration with multi-stakeholder certification programs. As a result, the formerly vague, partly secret, and merely nonbinding commitment was considerably improved and implemented.

While Backer focuses on the internal organizational perspective of multinational corporations and the internal effects of external pressure, Gavin Anderson reverses the perspective and investigates the constitutional potential of external pressure, more concretely, of social movements. ${ }^{67}$ The lack of any institutionalized organizational structure, their grounding in non-Western culture, and their critical potential makes it, at first sight, difficult to include social movements in constitutional theory, but societal constitutionalism attempts to do so and thus represents in this regard a novelty by recognizing social actors as constitutional subjects. Nevertheless, even societal constitutionalism, he submits, seems so far to favor institutionalized constitutional subjects (corporations, trade organizations). By connecting the "globalization from below" literature to constitutional theory, Anderson

65. See generally Backer, supra note 26.

66. Id. at 858 .

67. See generally Gavin W. Anderson, Societal Constitutionalism, Social Movements, and Constitutionalism from Below, 20 IND. J. GLOBAL LEGAL STUD. 881 (2013). 
argues for an understanding of social movements as constitutional subjects, as inherent parts of the political, albeit in a noninstitutionalized, unordered way.

To make sense of social movements as constitutional subjects, constitutional theory needs to undergo a fundamental transformation, since social movements transcend the traditional political dichotomy of reform and revolution. They seek neither to seize nor to abandon power, but rather they seek to change the power relations as such. In order to capture this specific characteristic in the constitutional discourse, Anderson suggests nodal governance as a framework for constitutional theory, in which different nodes act within a plurality of networks and may be connected to each other without a need for these nodes to be formally institutionalized.

\section{Constitutional Arenas}

How does societal constitutionalism function in practice? What conditions have to be fulfilled in order to define a social process as a constitutional development? And what do the specifics of each of these different constitutional processes imply for the further development of the theory? The authors in this section choose specific case studies to show where constitutional processes in global society can be observed and which conclusions for societal constitutionalism can be drawn. They identify constitutional processes in various fields: societally crafted regimes of intellectual property, international financial account standard-setting, the commons movement, the regime of fundamental rights, and the certification programs for sustainable forestry and fishery.

In the field of intellectual property (IP), Dan Wielsch identifies constitutional processes in what he calls societally crafted IP regimes generated by private actors and draws conclusions for the future of IP law. ${ }^{68}$ Wielsch argues that, while the present international IP regime constituted under the World Trade Organization (WTO)/Trade Related Aspects of Intellectual Property Rights (TRIPS) trade regime extensively protects the economic exploitation of intellectual property by the author, other social interests relevant for IP rights, become remarkably underrepresented. This, however, seems highly problematic because decentralized knowledge production is pivotal for any social order. In order to overcome this deficit in international IP law, Wielsch argues that IP law, instead of autonomously constructing the institution

68. See generally Dan Wielsch, Private Governance of Knowledge: Societally-Crafted Intellectual Properties Regimes, 20 IND. J. Global LEGAL STUD. 907 (2013). 
of property along economic logic, should focus on decentralized social knowledge production and on the relation between the rights of the author and society's right to access in particular. Wielsch sees the way forward in alternative models of knowledge production initiated by private actors, such as copyleft or standard license agreements. Alternative IP models occupy the legal form of existing IP rights but employ them for a different mode of knowledge production. Alternative IP models subordinate existing IP rights under their own community standards and social conventions and hereby render possible a communicative process of knowledge generation that restricts the economic dominance of IP rights. More concretely, Wielsch shows how authors open their IP rights to a broader community via standard license agreements, but they can only do so under the condition that any follow-up products are again licensed under the community rules. Such alternative models of knowledge production that employ IP rights, but transform them according to the needs of shared knowledge production, may prevent the dominance of economic rationality in IP law.

Moritz Renner analyses international financial accounting standards. $69 \mathrm{He}$ interprets societal constitutionalism as a process in which the system at stake is closely coupled to the legal and political system. For him, societal constitutionalism attempts to combine central elements of two theory traditions-social-democratic economic democracy and ordo-liberal economic constitutionalism. In international financial accounting standards, Renner sees both constitutive and limitative rules evolving. The former can be identified in the evolving hierarchy of norms. The central document of the International Accounting Standards Committee (IASC) contains rules about how the standards can be adopted, changed, and implemented. These standards become hierarchically connected to national law as European disclosure law refers to them as the applicable standard. The limitative element in transnational accounting standards is represented in the interrelations between this legal process of international accounting and the political system, which is established primarily by means of a stakeholder consultation phase in the standard-setting process.

Saki Bailey and Ugo Mattei analyze constitutional processes initiated and driven by social movements. ${ }^{70}$ Employing insights from critical constitutional theory and practical experience from the Italian commons movements - the social movement against privatization of public services--they argue that social movements may indeed become a

69. See generally Moritz Renner, Occupy the System! Societal Constitutionalism and Transnational Corporate Accounting, 20 IND. J. GLOBAL LEGAL STUD. 941 (2013).

70. See generally Saki Bailey \& Ugo Mattei, Social Movements as Constituent Power: The Italian Struggle for the Commons, 20 IND. J. GLOBAL LEGAL STUD. 965 (2013). 
constitutional counter force against the hegemonic project of economic constitutionalism. In a first step, they describe how, in the history of modern liberal constitutions, the paradox of constituent power-its double character as the constitutionally determined "people" presupposing and being institutionalized in the constitution and as the "raw" power preceding and enacting a constitution-has become concealed by an emphasis on the former character and its autonomous institutionalization. As an important development of this process, private property has become embedded into the constitutional structure, resulting in an incontestable institution beyond the reach of institutionalized constituent power. To render the institution of private property constitutionally contestable, Bailey and Mattei look to the deinstitutionalized element of constituent power in the form of social movements.

The Italian referendum against privatization of the public service of water supply shows how a broad civil society coalition consisting of scholars, political activists, cultural institutions, and environmental groups successfully initiated a constitutional referendum that resulted in the privatization of the water supply against the will of national politicians and the pressure of the European Union institutions. While Bailey and Mattei consider this as a successful instance of societal constitutionalism from below, they also realize that this success requires the commons movement to become subject to a self-constitutionalizing process.

Florian Rödl deals with fundamental rights in societal constitutionalism. ${ }^{71}$ Fundamental rights may in fact serve as a societal constitutional category that is explicitly not limited to politics and public law but is inherent to private law. From the perspective of moral philosophy, Rödl perceives private law as the core of societal constitutionalism and focuses in particular on the relation between private law and democratic rights. Democratic rights are indispensable for the functioning of a political order and thus also for enacting private law; they can be understood as legitimizing private law. Since the democratic parliamentary process in turn presupposes a society constituted by fundamental rights to be legitimate itself, the political process logically presupposes a societal understanding of fundamental rights. Fundamental rights then represent societal institutions with the result that private law becomes genuine constitutional law. In relation to the transnational constellation, this requires an understanding of fundamental rights as universal in substance and not limited to any

71. See generally Florian Rödl, Fundamental Rights, Private Law, and Societal Constitution: On the Logic of the So-Called Horizontal Effect, 20 IND. J. GLOBAL LEGAL STUD. 1015 (2013). 
specific national public order; rather, fundamental rights have to be conceptualized within private law itself irrespective of what the national constitution prescribes. Rödl emphasizes that this concept would not only require state courts, but also require nonstate court-like institutions such as commercial arbitration or the Internet Corporation for Assigned Names and Numbers (ICANN) disputes to understand fundamental rights as private law rights.

In the final contribution, Jaye Ellis examines certification programs for sustainable fishery and forestry as a form of societal constitutionalism in the interrelation between different social fields, namely economics, politics, ethics, science, and law. ${ }^{72}$ While acknowledging their different rationalities as important for these certification programs to form a constitutional network, she emphasizes the risks of such close interrelations. They may jeopardize the autonomy of each of these rationalities, which, as a consequence, may seriously endanger the functioning of the network as such. Hence, societal constitutionalism requires not only connecting different rationalities, but also establishing mechanisms within the network that safeguard the autonomy of each of the rationalities at stake.

In her case study on certification programs, Ellis critically observes how the law's rationality, albeit being a crucial component in the process of self-limitation, is currently in great danger of being overwhelmed by other rationalities due to the incentive-based market structure of product certification and the scientific evidence on which the decision on issuing the certificate is based. She diagnoses the cause for this lack of legal autonomy in the tendency toward enacting vague principles instead of hard norms. Quite comparable to the materialization of the law in the welfare state, the legal rationality in the programs becomes unacceptably dependent on other social rationalities. As a way out, Ellis suggests that the certification programs would have to enact "stop-rules" that may safeguard the autonomy of the law against political, scientific, or economic domination.

Together, these contributions can be read as ideas on how the theory of societal constitutionalism could be further developed and as instructive illustrations as to where societal constitutions already emerge in today's world society.

72. See generally Ellis, supra note 52 . 